\title{
Jưưál Hâuá
}

Studi Pengarus Utamaan Gender dan Anak https://ejournal.iainbengkulu.ac.id/index.php/hawa
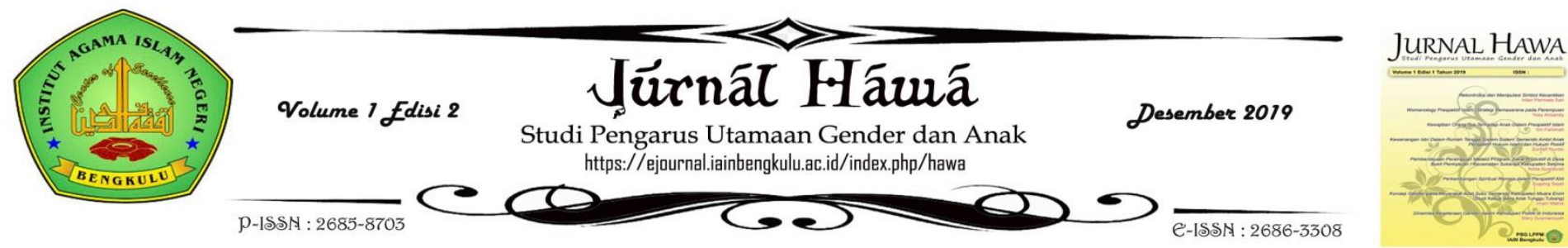

\section{Pola Komunikasi Interpersonal dalam Konflik Perkawinan: Studi Pada Pasangan Suami Istri Periode Tahun Awal di Kota Bengkulu}

\section{Info Artikel} Diterima: Oktober 2019 Disetujui: Oktober
2019

\section{Dipublikasikan: \\ Desember 2019}

\section{Keyword}

\section{Interpersonal} communication, conflict, marriage, early year period

\author{
Dita Verolyna, Alex Abdu Chalik, Heri Supriyanto \\ ditaditut01@gmail.com \\ IAIN Curup dan Universitas Bengkulu
}

\section{Kata Kunei}

Komunikasi interpersonal, konflik, perkawinan, periode tahun awal.

\section{Abstract}

Interpersonal Communication Patterns in Marriage Conflict: Study of Husband and Wife in the Early Years Period in the City of Bengkulu. The purpose of this study is to find out how interpersonal communication patterns in marital conflict. This research was conducted on a marriage partner in the Early Years period in Bengkulu City. The research method in this research is descriptive qualitative and life history. Data obtained through in-depth interviews, observation, and literature. Informants were interviewed as many as seven families. Data analysis using the Miles and Huberman models. The results of research on Interpersonal Communication Patterns in marital conflict in seven husband and wife periods of the early years there are adjustments in the marriage of the early years period. These adjustments include adjusting spouse, sexual, financial and family of the spouse. From the seven families the results are obtained (1) Adjustment of partners, all couples experience obstacles in adjusting all the differences between the two (2) financial adjustment, conflicts often occur in informant couples whose husband and wife work and couples whose husbands are low income. (3) sexual adjustments, barriers occur to informants whose partners have health problems and have many children. (4) adjustments to the spouse's family. Conflicts occur in couples who live in in-laws' homes and have children from previous marriages. (5) Separate equal and balanced communication patterns are used in adjustments to partners. (6) Separate unbalanced communication patterns and monopoly are used in marital conflicts caused by financial, sexual and financial adjustments to the couple's family. Thus in the early days of marriage there were almost conflicts between couples. The conflict occurred because indeed during the early year period, there were differences between husband and wife and other family members so that an appropriate communication pattern was needed to resolve the conflict.

\section{Abstrak}

Pola Komunikasi Interpersonal dalam Konflik Perkawinan: Studi Pada Pasangan Suami Istri Periode Tahun Awal di Kota Bengkulu. Tujuan penelitian ini untuk mengetahui bagaimana pola komunikasi interpersonal dalam konflik perkawinan. Penelitian ini dilakukan pada pasangan perkawinan periode Tahun Awal di Kota Bengkulu. Metode penelitian dalam penelitian ini adalah kualitatif desrkriptif dan life history. Data diperoleh melalui wawancara mendalam, observasi, dan kepustakaan. Informan yang diwawancarai sebanyak tujuh keluarga. Analisis data menggunakan model Miles dan Huberman. Hasil penelitian tentang Pola Komunikasi Interpersonal dalam konflik perkawinan pada tujuh pasangan suami istri periode tahun awal adalah terdapat penyesuaian-penyesuian dalam perkawinan periode tahun awal. Penyesuaian tersebut meliputi penyesuaian pasangan, seksual, keuangan dan terhadap keluarga pasangan. Dari ketujuh keluarga diperoleh hasil (1) Penyesuaian pasangan, semua pasangan mengalami hambatan dalam menyesuaikan semua perbedaan di antara keduanya (2) penyesuaian keuangan, konflik sering terjadi dalam pasangan informan yang suami istri bekerja dan pasangan yang suaminya berpenghasilan rendah. (3) penyesuaian seksual, hambatan terjadi pada informan yang pasangannya mengalami gangguan kesehatan dan telah memiliki banyak anak. (4) penyesuaian terhadap keluarga pasangan. Konflik terjadi pada pasangan yang tinggal di rumah mertua dan memiliki anak dari pernikahan sebelumnya. (5) Pola komunikasi setara dan seimbang terpisah digunakan pada penyesuaian terhadap pasangan. (6) Pola komunikasi tak seimbang terpisah dan monopoli digunakan dalam konflik perkawinan yang disebabkan oleh hambatan penyesuaian keuangan, seksual dan penyesuaian terhadap keluarga pasangan. Dengan demikian pada masa awal perkawinan hampir ditemui konflik antar pasangan. Konflik terjadi karena memang pada masa periode tahun awal, terdapat perbedaan antara suami istri dan anggota keluarga lainnya sehinga diperlukan pola komunikasi yang tepat untuk mengatasi konflik tersebut. 
Dita Verolyna, Alex Abdu Chalik, dan Heri Supriyanto: POLA KOMUNIKASI INTERPERSONAL DALAM KONFLIK PERKAWINAN: Studi Pada Pasangan Suami Istri Periode Tahun Awal Di Kota Bengkulu

\section{Pendahuluan}

Keluarga harmonis adalah dambaan semua pasangan yang telah menikah. Dalam keluarga harmonis diperlukan hubungan timbal balik dengan menciptakan sikap saling pengertian, terbuka, menjaga, menghargai, dan saling memenuhi kebutuhan antara satu sama lain. Harmonisasi dalam keluarga akan membuat bahagia dalam menjalaninya.

Suatu pernikahan yang harmonis sulit terwujud tanpa adanya hubungan interpersonal yang baik antara suami dengan istrinya. Agar suasana hubungan yang baik dapat terwujud diperlukan suasana yang hangat, penuh pengertian, penuh kasih sayang satu dengan lainnya agar dapat menimbulkan suasana yang akrab.

Beberapa faktor yang mempengaruhi dalam keharmonisan keluarga di antaranya adalah saling mencintai, baik dalam hal fisik kedua belah pihak, material, pendidikan, agama.

Kenyataannya saat seorang pria dan wanita menikah, tentunya mereka membawa nilainilai budaya, sikap, dan keyakinan masing-masing ke dalam pernikahan tersebut. Dalam menghadapi perbedaan- perbedaan tersebut, pasangan suami istri harus melakukan penyesuaian untuk membentuk nilai dan sistem baru bagi keluarga mereka.

Perbedaan-perbedaan itu akan terbawa pada saat terjadi proses penyesuaian antara suami dan istri. Penyesuaian adalah proses saling mengenal suami istri terhadap pasangannya. Baik itu terhadap kebiasaan seharihari, penetapan aturan rumah tangga dan cara pandang dalam memutuskan tujuan dalam pernikahan.

Dalam perkawinan akan terjadi beberapa proses penyesuaian yaitu penyesuaian terhadap pasangan, hubungan seksual, keuangan, dan terhadap keluarga pasangan. Penyesuaian ini akan terasa sulit jika berada pada kondisi tertentu, karena sedikitnya masa pengenalan, perbedaan latar budaya, pernikahan yang dijodohkan, dan konsep yang tidak realistis dalam perkawinan. Hambatan ini sewaktu-waktu dapat memicu konflik.

Walaupun konflik merupakan hal yang dianggap wajar dalam hubungan pernikahan, konflik tidak bisa disepelekan. Saat konflik terjadi, pasangan harus 
menyelesaikannya agar hubungan kembali terjalin dengan baik. Jika diselesaikan dengan cara yang baik, konflik dapat membuat individu bertambah matang dan bisa memperkuat hubungan mereka (Wood, 2013).

Konflik dapat membuat hubungan semakin dekat atau sebaliknya tergantung dari bagaimana cara menangani masalah. Hal terburuk yang terjadi jika konflik tidak kunjung selesai adalah perceraian. Kesulitan berkomunikasi, intoleransi, dan tidak menghargai pasangan membuat pertikaian muncul dan bercerai seringkali dianggap sebagai jalan terbaik.

$$
\text { Pola komunikasi }
$$

interpersonal yang baik tentunya akan sangat mendukung untuk menciptakan hubungan yang positif tersebut. Menurut DeVito (2013) terdapat empat pola komunikasi interpersonal yaitu persamaan, seimbang terpisah, tak seimbang terpisah dan monopoli. Keempat pola komunikasi tersebut menggambarkan bagaimana situasi konflik yang terjadi dalam perkawinan.

Peneliti merasa penelitian tentang konflik perkawinan masih penting dan menarik untuk diteliti karena akan berguna untuk mengetahui pola komunikasi interpersonal pasangan suami istri dalam menyelesaikan konflik pada perkawinan periode tahun awal. Pengelolan konflik yang efektif dapat menumbuhkan sikap terbuka antara satu dan lainnya. Berdasarkan latar belakang masalah yang telah diuraikan, maka rumusan masalah dalam penelitian ini adalah bagaimana Pola komunikasi Interpersonal Pasangan Suami Istri Dalam Konflik Pada Perkawinan Periode Tahun awal?

\section{Kajian Literatur}

Manusia merupakan makhluk yang paling sempurna, tetapi dalam hidupnya ia tidak bisa hidup sendiri, membutuhkan orang lain dan selalu bersama dengan yang lain. Oleh karena itu manusia disebut sebagai makhluk sosial. Untuk mewujudkan itu semua, maka salah satu cara yang bisa dilakukan adalah melalui perkawinan.

Menurut Walgito (2005), terdapat tiga periode dalam perkawinan yaitu :

a. Tahun awal (early years) 
Dita Verolyna, Alex Abdu Chalik, dan Heri Supriyanto: POLA KOMUNIKASI INTERPERSONAL DALAM KONFLIK PERKAWINAN: Studi Pada Pasangan Suami Istri Periode Tahun Awal Di Kota Bengkulu

Masa ini mencakup kurang lebih 10 tahun pertama perkawinan.

b. Tahun pertengahan (midlle years)

Periode ini berlangsung antara tahun kesepuluh sampai dengan tahun ketiga puluh dari masa perkawinan. Masa yang terjadi pada tahap ini adalah "Child full phase" yang kemudian diikuti oleh "Us aging phase".

c. Tahun matang (mature years)

Masa ini dimulai pada tahun ketiga puluh dalam perkawinan. Pasangan suami istri berada dalam peran yang baru, misalnya bertindak sebagai kakek atau nenek, menikmati hari tua bersamasama atau hidup sendiri lagi karena salah satu pasangan telah meninggal lebih dulu.

Hurlock (2004) menyebutkan, Faktor-faktor dalam penyesuaian pernikahan terbagi menjadi empat, antara lain:

a. Penyesuaian pasangan

b. Penyesuaian seksual

c. Penyesuaian keuangan

d. Penyesuaian dengan pihak keluarga pasangan.

Kata konflik berasal dari bahasa latincon yang berarti bersama dan fligere yang berarti benturan atau tabrakan. Konflik dalam kehidupan sosial berarti benturan kepentingan, keinginan, dan pendapat yang melibatkan dua pihak atau lebih. Secara sosiologis, konflik diartikan sebagai suatu proses sosial atau dua orang atau lebih, atau kelompok dimana salah satu pihak berusaha menyingkirkan pihak lain dengan menghancurkannya atau membuatnya tidak berdaya (DeVito, 2013)

Djamarah

mendefinisikan, Pola komunikasi adalah bentuk hubungan dua orang atau lebih dalam proses pengiriman dan penerimaan cara yang tepat, sehingga pesan yang dimaksud dapat dipahami. Dimensi pola komunikasi terdiri dari dua macam, yaitu pola yang berorientasi pada konsep dan pola yang berorientasi pada sosial yang mempunyai arah hubungan yang berlainan (Berger, 2014).

De Vito dalam bukunya Interpersonal Communication (2013) mengungkapkan empat pola komunikasi keluarga pada umumnya, yaitu :

1. Pola Komunikasi kesetaraan

2. Pola Komunikasi seimbang terpisah 
3. Pola Komunikasi Tak seimbang terpisah

4. Pola Komunikasi monopoli

Tradisi psikologis dapat dibagi kedalam tiga cabang besar yaitu perilaku, kognitif dan biologis. Dalam wilayah kognitif terdapat teori atribusi, penilaian sosial, dan kemungkinan elaborasi. Teori tersebut telah menjadi dasar untuk tradisi psikologis memahami bagaimana interpretasi dan persuasi terjadi di antara individu (Littlejhon, 2014).

Teori atribusi adalah proses dengan mana kita mencoba memahami perilaku orang lain selain juga perilaku kita sendiri. Kita menilai dan memahami alasan atau motivasi perilaku perilaku (Devito, 2014). Teori ini diperkenalkan oleh Heider pada tahun 1985 melalui bukunya yang berjudul The Psychologi Interpersonal Relation.

\section{Metode Penelitian}

Penelitian ini menggunakan paradigma kualitatif dengan jenis penelitian deskriptif dan life history. Dalam penelitian ini data primer bersumber dari hasil wawancara yang dilakukan oleh peneliti kepada informan tentang bagaimana proses penyesuaian yang mereka hadapi dalam perkawinan. Data sekunder peneliti dapatkan dari bukubuku, jurnal dan penelitian yang berkaitan dengan pola komunikasi dalam konflik perkawinan periode tahun awal. Data-data tersebut kemudian diolah untuk mendapatkan data yang otentik.

Penelitian ini memiliki dua jenis informan yaitu informan pangkal dan informan kunci yang ditetapkan dengan kriteria tertentu.

Ada beberapa teknik atau metode yang dapat digunakan peneliti dalam mengumpulkan data yang dikenal dengan observasi, wawancara, mendalam dan studi dokumentasi (Kriyantono, 2006).

Untuk menganalisis data penelitian ini akan digunakan analisis data model interaktif Milles dan Huberman (1992: 90) yaitu terdapat tiga proses yang belangsung secara interaktif.

Pertama, reduksi data, yaitu proses memilih memfokuskan, menyederhanakan, dan mengabtraksikan data dari berbagai sumber data misalnya dariv catatan lapangan, dokumen, arsip, dan sebagainya. sedangkan proses mempertegas, memperpendek membuang yang tidak perlu menentukan fokus 
Dita Verolyna, Alex Abdu Chalik, dan Heri Supriyanto: POLA KOMUNIKASI INTERPERSONAL DALAM KONFLIK PERKAWINAN: Studi Pada Pasangan Suami Istri Periode Tahun Awal Di Kota Bengkulu

dan mengatur data sehingga kesimpulan bisa dibuat.

Kedua, Penyajian data, seperti merakit data dan menyajikan dengan baik supaya lebih mudah dipahami, penyajian bisa berupa matrik, gambar, skema, jaringan kerja, tabel dan narasi. Ketiga, menarik kesimpulan/verifikasi, proses penarikan kesimpulan awal harus kuat dan terbuka, kesimpulan akhir dilakukan setelah pengumpulan data berakhir.

\section{Pembahasan}

Informan berjumlah tujuh keluarga dengan karakteristik yang berbeda-beda. Keluarga pertama mengetengahkan Beni dan Rima, sepasang suami istri yang sama-sama bekerja. Dari hasil penelitian ditemukan bahwa penyesuaian yang terjadi pada keluarga Beni dan Rima adalah penyesuaian keuangan dan lebih dekat ke arah hubungan kompetitif. Pola komunikasi dalam keluarga ini adalah pola komunikasi tak seimbang terpisah, karena Rima sangat mendominasi Beni karena penghasilannya lebih besar daripada suaminya.

Keluarga kedua mengetengahkan pasangan Kevin dan Karin, sepasang suami istri yang hanya istri saja memiliki pekerjaan tetap. Keduanya tidak terlalu mementingkan masalah keuangan karena Karin berasal dari keluarga berada. Pasangan ini mengalami penyesuaian seksual karena Kevin seorang penderita HIV. Bagaimanapun juga, penyakit ini cukup membuat repot kehidupan seksual keduanya, meskipun mereka menyatakan bahwa saling menerima apa adanya. Pola komunikasi dalam keluarga ini cenderung setara karena sama-sama menghargai kontribusi masing-masing dalam keluarga kecil mereka.

Keluarga ketiga ini mengetengahkan pasangan suami istri Jemi dan Jesi, yang sama-sama pernah menikah sebelumnya. Keduanya memiliki anak dari pernikahan sebelumnya tetapi hanya anak Jesi saja yang tinggal bersama mereka. Anak Jemi menetap bersama Jenita-mantan istri Jemi di Kota Bandung. Pasangan ini khususnya Jesi kesulitan melakukan penyesuaian dengan keluarga pasangan karena pernikahan mereka tidak disetujui oleh orang tua Jemi. Pola komunikasi yang diterapkan Jemi kepada anak tirinya merupakan pola komunikasi 
monopoli karena bersifat satu arah.

$\begin{array}{cr}\text { Keluarga } & \text { keempat } \\ \text { mengetengahkan } & \text { pasangan }\end{array}$

Yoyon dan Yohana, merupakan keluarga terkaya dalam penelitian ini. Namun penyesuaian yang mereka hadapi adalah penyesuaian seksual karena Yoyon merasa Yohana terlalu sibuk dengan anak-anak mereka hingga kehilangan waktu untuk berduaan. Akibatnya Yoyon selingkuh dengan pengasuh anaknya, Yosi. Meskipun demikian, karena perkawinan mereka sudah memasuki tahun kesepuluh maka Yohana memiliki kebijaksanaan lebih tinggi dalam menyelesaikan masalah.

Keluarga

kelima

mengetengahkan pasangan

Darius dan Dona, pasangan yang dijodohkan, merupakan paman dan kemenakan, dan memiliki rentang umur yang jauh. Darius memiliki anak dari pernikahan sebelumnya bernama Dika, yang sangat diotorisasi oleh Dona. Selain itu, Darius juga mengidap penyakit diabetes sehingga mengalami gangguan kemampuan ereksi. Hal ini menyebabkan terganggunya relasi seksual antara keduanya.
Keluarga

keenam mengetengahkan pasangan Nugi dan Nunung yang baru saja menikah selama setahun. Mereka tinggal bersama Ibu Nugi dikarenakan ayahnya telah lama meninggal dunia. Nugi melarang Nunung bekerja dan memaksa untuk tetap tinggal dirumah orang tuanya. Nunung merasa Ibu mertuanya terlalu otoriter dalam kehidupan perkawinan mereka dan Nunung sulit menyesuaikan diri dengan keluarga pasangannya itu.

Keluarga ketujuh mengetengahkan pasangan Fandi dan Fina yang menikah di usia muda. Kala itu Fandi dan Fina masih sama-sama berstatus pelajar. Keduanya tinggal di rumah orang tua Fandi, Hera. Hera sangat keras kepada menantunya. Alasannya karena dia terpaksa merestui pernikahan itu karena Fina terlanjur berbadan dua. Keluarga kecil ini mengalami kesulitan menyesuaikan diri terhadap tanggung jawab keuangan dan keluarga pasangan. Sedangkan pola komunikasinya berbentuk monopoli.

Proses penyesuaian dalam tiap keluarga berbeda-beda. Menurut Hurlock (2004) penyesuaian tersebut meliputi empat aspek, yaitu penyesuaian 
Dita Verolyna, Alex Abdu Chalik, dan Heri Supriyanto: POLA KOMUNIKASI INTERPERSONAL DALAM KONFLIK PERKAWINAN: Studi Pada Pasangan Suami Istri Periode Tahun Awal Di Kota Bengkulu

pasangan pasangan, keuangan, seksual, dan terhadap keluarga pasangan. Dalam menyelesaikan konflik akibat penyesuaian tersebut terdapat pola komunikasi yang diterapkan dalam keluarga.

Teori Atribusi yang dikategorikan dalam tradisi sosiopsikologis menyebutkan bahwa setiap individu mencoba untuk memahami perilaku mereka sendiri dan orang lain dengan mengamati bagaimana sesungguhnya mereka berperilaku. Sebagai pelaku komunikasi, manusia harus berpikir logis mengapa kita sampai berperilaku demikian dan terkadang kita ingin memaparkan mengapa orang lain bisa berperilaku seperti itu.

Heider, sang penemu teori merupakan psikolog berkebangsaan Austria yang kemudian menetap ke Amerika. Heider banyak melakukan penelitian tentang psikologi sosial pada kehidupan masyarakat di sana. Gaya atribusi orang Amerika sangat berbeda dengan Asia. Orang Amerika cenderung memiliki konsep diri yang independen. Di kebudayaan barat keterpisahan individu menjadi keyakinan yang kuat. Tugas normatif budaya ini adalah untuk mempertahankan independensi atau kemandirian individu sebagai entitas yang terpisah dan self-contained (terbatas pada diri).
Masyarakat barat terbiasa tumbuh menjadi sesuatu yang "istimewa" dan "unik". Kebudayaan Amerika menyediakan tugas-tugas seperti ini bagi anggotanya.

Banyak dari tugas kultural yang ada dalam budaya Amerika saat ini dirancang dan diseleksi, melalui sejarah, untuk mendorong terbentuknya independensi atau ketidaktergantungan masingmasing diri yang terpisah.

Dengan adanya tugas-tugas kultural seperti ini, pengertian orang Amerika tentang harga diri atau nilai diri pun mengambil bentuk yang khas. Ketika individu berhasil menjalani tugas-tugas kultural ini, mereka akan sangat puas dengan dirinya. Mereka sangat menghargai dirinya.

Kebiasaan non-barat berbanding terbalik karena tidak menghargai keterpisahan yang terlihat itu. Budaya pada orang Asia menekankan pada apa yang dinamai keterikatan yang mendasar pada manusia. Sehingga orang Asia dituntut untuk melakukan penyesuaian diri untuk menjadi ideal dan mempertahankan interdependensi diantara individu. Akibatnya, masyarakat Asia dibesarkan untuk menyesuaikan diri dengan orang lain dalam suatu kelompok atau membaca maksud orang lain, atau menjadi orang yang ramah atau berindak sesuai tata karma. 
Itu mengapa dalam
penelitian ini, ada beberapa
keluarga hidup
perkawinan yang sebenarnya
jauh dari kata bahagia, namun
selalu berusaha menjalani dengan
tabah. Sebagaimana dengan
budaya masyarakat Asia yang
kurang menghargai dirinya
sendiri dan memiliki keterikatan
kuat dengan orang-orang
disekitarnya. Cara hidup berkelompok atau kolektivistik membuat orang-orang Asia memikirkan lingkungannya ketika akan mengambil sesuatu keputusan. Akibatnya, mereka cenderung seperti paku yang terpaksa diratakan dengan papan, karena tidak mampu mengekspresikan sesuatu diluar kebiasaan budayanya.

Karakteristik individualis orang Eropa menyebabkan popularitas ilmu psikologi sosial yang menaungi teori atribusi kurang popular karena sangat bertentangan dengan sifat ajarannya yakni kolektivis. Kemudian jika dilihat dari high context and low context communication, terdapat detail pembeda seperti rasa ikatan kelompok dan komitmen terhadap hubungan dengan orang lain. Masyarakat yang menganut budaya konteks tinggi lebih suka menjalin hubungan jangka panjang dan berkomitmen tinggi. Berbanding terbalik dengan budaya konteks rendah yang komitmennya lebih longgar terhadap sesama.

Teori atribusi berhubungan dengan bagaimana menyimpulkan hal yang menyebabkan perilaku kita dan perilaku orang lain. Terdapat beberapa hal yang menyebabkan mengapa orang berperilaku seperti pengaruh lingkungan, pengaruh pribadi, kemauan, usaha, hasrat (keinginan untuk melakukannya), perasaan, keterlibatan, kewajiban dan perizinan.

Seperti mengapa orang cenderung bersikap tradisional karena lingkungan yang menyebabkan hal itu harus dilakukan. Pembagian tugas secara terpisah misalnya disebakan oleh lingkungan yang berperilaku sama. Semua yang dilakukan oleh ketujuh keluarga ini disebabkan oleh hal-hal yang dikemukakan dalam teori atribusi. Kemauan untuk menjaga kelanggengan hubungan dalam keluarga menyebabkan orang tidak mau lama-lama berkonflik atau sebaliknya. Perasaan juga menjadi penyebab kuat dalam membina rumah tangga yang saling mencintai.

Atribusi banyak dipengaruhi oleh psikologis 
Dita Verolyna, Alex Abdu Chalik, dan Heri Supriyanto: POLA KOMUNIKASI INTERPERSONAL DALAM KONFLIK PERKAWINAN: Studi Pada Pasangan Suami Istri Periode Tahun Awal Di Kota Bengkulu

sehingga memunculkan persepsi. Seringkali suami atau isteri seperti dalam keluarga yang dikemukakan dalam penelitian ini mengartikan apa yang mereka lihat dari pasangannnya. Mereka akan cenderung menyalahkan suami atau istrinya jika kesalahan itu diperbuat oleh pasangannya. Namun sebaliknya, ketika mereka melakukan kesalahan, faktor situasional akan dituduh menjadi penyebab terjadi kesalahan itu. Tetapi di Bengkulu, dan khususnya pada keluarga-keluarga dalam penelitian ini, kebanyakan dari mereka tidak menyalahkan faktor situasional tetapi lebih kepada dirinya sendiri.

Terlebih lagi pada kaum wanita, mereka seolah terikat pada aturan untuk menerima dan tidak menyalahkan situasi ketika terjebak dalam situasi yang sulit. Namun begitu, ada juga beberapa wanita yang memiliki kepercayaan dan menghargai dirinya sehingga mampu menerapkan bias mementingkan diri sendiri.

Pada kerangka berpikir yang dikemukakan di bab sebelumnya dijelaskan bahwa penyesuaian yang berjalan tanpa hambatan akan membentuk harmoni dalam perkawinan. Namun kenyataannya, tidak pernah ada perkawinan yang benar-benar harmoni. Pasangan menikah akan menemukan banyak perbedaan diantara mereka sehingga timbul gesekan- gesekan yang berujung pada konflik.

Konflik terjadi naik turun, tidak ada yang mampu meramalkan masalah apa saja yang akan muncul dalam perkawinan. Tetapi pada pasangan yang mampu mengelola konflik ini secara konstruktif, hubungan akan kembali membaik dan erat sehingga fase bulan madu terus berulang pasaca konflik.

\section{Kesimpulan}

Dari tujuh keluarga, hampir seluruhnya mengalami hambatan ketika melakukan penyesuaian terhadap pasangan. Informan yang mengalami kesulitan dalam penyesuaian keuangan adalah informan yang sama-sama bekerja dan suami yang tidak bekerja. Hambatan penyesuaian seksual dialami oleh informan yang memiliki banyak anak dan salah satu pasangannya mengalami gangguan kesehatan. Sedangkan hambatan penyesuaian terhadap keluarga pasangan dirasakan oleh perkawinan yang tidak disetujui oleh orang tua dan pasangan yang tinggal seatap dengan orang tua. Hambatan penyesuaian ini mengakibatkan terjadinya konflik dalam perkawinan pasangan.

Berdasarkan pembahasan, maka saran penelitian ini ditujukan kepada peneliti selanjutnya yaitu sebagai berikut:

Peneliti selanjutnya dapat mengkaji lebih dalam mengenai pola komunikasi interpersonal 
dengan karakteristik keluarga yang lebih bervariasi dan pengaruh kecanggihan teknologi terhadap hubungan dan komunikasi dalam keluarga.

Peneliti diharapkan pula dapat lebih mengeksplor permasalahan dalam keluarga karena penelitian yang mendetail tentang konflik dalam keluarga

\section{DAFTAR PUSTAKA}

Basri, Hasan. 2005. Keluarga Sakinah Tinjauan Psikologis dan Agama. Edisi Empat. Yogyakarta: Pustaka Pelajar.

Berger, R. Charles, dkk. 2014. Handbook Ilmu Komunikasi. Terjemahan Derta Sri widowati. Bandung : Nusa Media

Bungin, Burhan. 2014. Sosiologi Komunikasi. Jakarta :

Kencana Prenadamedia Group

DeFrain, J. \& Olson, D. 2003. Marriages and Families. New York: McGraw-Hill Book Company.

Devito, J.A. 2013. Interpersonal Communictaion. $13^{\text {th }}$ Edition. New Jersey: PEARSON.

Djamarah, Bahri, Syaiful. 2004. Pola Komunikasi Orang Tua dan Anak dalam Keluarga. Jakarta : PT.Reneka Cipta. belum banyak dilakukan dan menjalin rapport terlebih dahulu terhadap informan sehingga data yang didapatkan lebih dalam.

Peneliti selanjutnya dapat menambahkan perspektif lain tentang konflik antar keluarga pasangan, misal dari perspektif menantu, mertua, suami, istri, dan ipar secara spesifik.

Harapan, Edi dan Syarwani ahmad. 2014. Komunikasi Antar Pribadi : Perilaku Insani Dalam Organisasi Pendidikan. Jakarta : 2014

Hawari. 2013. Ilmu Kedokteran Jiwa dan Kesehatan Mental. Jakarta: Dana Bhakti Yasa.

Hidayat, Dasrun. 2012. Komunikasi Antarpribadi dan Medianya. Yogyakarta : Graha ilmu.

Hurlock, E. B. 2004. Psikologi Perkembangan, Edisi Kelima. Jakarta: Erlangga.

Koentjaraningrat. 1995. MetodeMetode Penelitian Masyarakat. Jakarta : PT.Gramendia

Kriyantono, R. 2006. Teknik Praktis Riset Komunikasi. Jakarta: Kencana Prenada Media Group.

Lestari, Sri. 2012. Psikologi Keluarga. Jakarta : 
Dita Verolyna, Alex Abdu Chalik, dan Heri Supriyanto: POLA KOMUNIKASI INTERPERSONAL DALAM KONFLIK PERKAWINAN: Studi Pada Pasangan Suami Istri Periode Tahun Awal Di Kota Bengkulu

Kencana Prenadamedia Group

Littlejohn, Stephen W. dan Foss, Karen A. 2014. Teori Komunikasi Theories of Human Communication. Edisi 9. Jakarta : Salemba Humanika.

Miles, B. Mathew dan Michael Huberman. 1992. Analisis Data Kualitatif Buku Sumber Ramulyo, Moh. Idris. 2010. Hukum Perkawinan Islam, Suatu analisis Dari UndangUndang Nomor 1 Tahun 1974 Dan Kompilasi Hukum Islam. Jakarta : Bumi Aksara

Sadarjoen, Sawitri Supardi. 2005. Konflik Marital. Bandung : Refika Aditama

Sarwono, S. (2006). Teori-teori Psikologi Sosial. Jakarta: Rajawali Press.

Sendjaja. Sasa Juarsa. 2014. Teori Komunikasi. Tangerang Selatan : Universitas Terbuka

Setiadi, Elly M. dan Usman Kolip. 2011. Pengantar Sosiologi.
Tentang Metode-metode Baru. Jakarta: UIP

Olson, D. F, DeFrain J, \& Skogrand L. 2011. Marriages Families: Intimacy, Diversity, and Strengths. New York: McGraw-Hill.

Pickering, Peg. 2005. How To Manage Conflict. Jakarta : Erlangga

Jakarta: Kencana Preneda Media Group

Soekanto, Soerjono. 2003. Sosiologi Keluarga: Tentang Ikhwa: Keluarga, Remaja, dan Anak. Rineka Cipta.Jakarta.

Strong, B., Christine D.V., \& Theodore F.C. 2010. The Marriage and Family Experience: Intimate Relationships in a Changing Society. Eleventh Edition. New York: Wadsworth.

Sugiyono.2016. Metode Penelitian Kuantitatif, kualitatif, dan $R \mathcal{E} D$, Bandung: Alfabeta 